\title{
Actual Date Range
}

National Cancer Institute

\section{Source}

National Cancer Institute. Actual Date Range. NCI Thesaurus. Code C93498.

The date and time span when the planned event or activity actually beg an and ended. 